\title{
Design and Development of Employment Vulnerability Index for Rural Youth
}

\author{
Renu Gangwar* and S.K. Kashyap \\ Department of Agricultural Extension and Communication, Govind Ballabh Pant University \\ of Agriculture and Technology, Pantnagar-263145, Uttarakhand, India \\ *Corresponding author
}

\begin{tabular}{|c|c|}
\hline & A B S T R A C T \\
\hline $\begin{array}{l}\text { Employment, Index, } \\
\text { Rural Youth, } \\
\text { Vulnerability, } \\
\text { Uttarakhand }\end{array}$ & \multirow{3}{*}{$\begin{array}{l}\text { In the developing nation like India unemployment is the matter of concern. Employment, } \\
\text { as an economic phenomenon with strong social implications. The global population of } \\
\text { young people aged } 15 \text { to } 24 \text { is more than one billion (IFAD, 2014). Unemployment among } \\
\text { rural youth is very high, forty per cent of youth population is vulnerable regarding } \\
\text { employment. Youth are the precious segment of the population as they play quite a } \\
\text { significant role in development. The study was conducted to know the employment } \\
\text { vulnerability of rural youth. This study describes the index that was developed to measure } \\
\text { the employment vulnerability of rural youth. The index consisted of } 46 \text { statements and } \\
\text { pilot study was done in Ringi village of Chamoli and Devar village of Rudraprayag } \\
\text { districts which indicate that it is reliable and consistent. The employment vulnerability } \\
\text { index can be used in other hilly regions of the India. }\end{array}$} \\
\hline Article Info & \\
\hline $\begin{array}{l}\text { Accepted: } \\
\text { 20 September } 2018 \\
\text { Available Online: } \\
10 \text { October } 2018\end{array}$ & \\
\hline
\end{tabular}

\section{Introduction}

Developing countries like India has a large youth population with great potential and strength. The global population of young people aged 15 to 24 is more than one billion (IFAD, 2014). Their numbers are declining in developed regions but increasing in developing regions. Seventy five million youth across the world was found unemployed in year 2011. Unemployment and poverty remain pervasive among rural youth who face numerous challenges in order to achieve and maintain their livelihood. In the developing world, high youth unemployment represents lost potential for national economic transformation and high numbers of economically frustrated youth may contribute to social instability. Most of the rural youth population work in family farming and the informal sector, which are typified by low levels of income, productivity, poor working conditions, lack of social protection and limited opportunities for advancement. The capacities of young rural people to contribute to rural development and transformation remain largely untapped and their potential unrecognized. Youth unemployment rate is generally observed to be higher than adult unemployment in developing nation. With the volatility of local economies in an era of recurrent global economic crises, the vulnerable position of youth within labour markets may become more solidified as they 
are often not the priority in the agenda of policy makers. If youth unemployment is not addressed, the youth will remain a risk factor in terms of economic and political stability in countries around the world. As a consequence of economic crisis, youth unemployment has risen dramatically and become a particular cause for concern. International Labour Organization is also trying to resolve these crises by taking action to tackle the youth employment problems through a multipronged approach that geared towards employment growth and decent job creation.

Youth are the precious segment of the population as they play quite a significant role in development. Youth population in India is 460 million, youth unemployment has risen (10.60 per cent) dramatically, around 40 per cent of youth population is vulnerable regarding employment. It was also recognized that the major causes of a high youth unemployment rate are lack of employability skills, lack of access to resources (land and capital), lack of focus of the existing programs in the informal sector and agriculture, lack of apprenticeship schemes, negative attitude of the youth towards work especially in agriculture, lack of comprehensive employment policy and negative cultural attitude such as gender discrimination. Young people are generally viewed as passive recipients of support, rather than active agents capable of solving problems. As such, they are rarely included in decision-making processes and they often face negative misconceptions about their skills and capabilities. This tends to feed into policy and planning processes, which are typically insensitive to youth. The undervaluing of youth capacities also manifests itself in barriers that constrain young people from participating in different activities.

Measuring the vulnerability of employment remains a challenging task for development practitioners because there is no appropriate tool available for assessment. This analysis requires the selection of suitable indicators that can only be achieved with great skills and awareness of all relevant factors. An analysis of youth livelihood can support the necessary broadening of the concept of vulnerability and lead to capture the dynamics of intergenerational factors and their influence on the sustainability of new employment opportunities. Moreover, such analyses often lead to a dynamic and long term perspective on sustainable livelihood through exploring the intergenerational aspects of livelihood inheritance and the relationship between opportunities and vulnerabilities. Sustainable livelihood approach was used to determine factors that influenced employment vulnerability among rural youth that helps to provide relevant information for extension functionaries, researchers and governments in making policies on risk mitigation and adaptation. This livelihood approach was used to design and develop employment vulnerability index to assess the employment vulnerability of rural youth. This vulnerability index builds upon the factors responsible for employment generation, outcomes and livelihood strategies.

\section{Materials and Methods}

In the present study construction of index to measure employment vulnerability of rural youth was done in various stages. According to Pedhazur and Schmelkin (1991), the first step in index construction is identification of an applicable theoretical framework addressing the phenomena of interest. An index may be defined as a technique of totaling or reducing a single composite series data on a number of distinct, but related variables expressed in different units of measurement (Hooda, 2001). In this study, different sustainable livelihood approaches were used as a model to determine 
employment vulnerability of rural youth. The following steps were considered for constructing the index:

\section{Collection and editing of the statements}

Sustainable livelihood approach was adopted to develop the index. The index in the present study consisted of five (Human, Financial, Social, Physical and Natural capitals) major indicators related to employment.

Each indicator consists of number of sub indicators, under it. Sub indicators were selected after consultation with experts and different literature. In the first stage, 68 statements were collected. During the second stage these statements were edited in accordance with the criteria suggested by Edward (1957). At the end of this process 46 statements were retained.

\section{Relevancy test}

Relevancy test was administered to find out the relevancy of these 68 statements for inclusion in the index to measure the employment vulnerability of rural youth in the hill of Uttarakhand. The items were subjected to judgment of 30 judges. The judges were requested to go through the items and indicate their relevancy on three point continuum as 'very much relevant', 'relevant' and 'not relevant' with corresponding scores of 3,2 and 1 respectively. All the judges responded within two month. By summing up the score given by each respondent, total score of all the 68 statements was calculated. From this data, relevancy percentage, relevancy weightage and mean relevancy scores were calculated using the following method:

\section{Relevancy Percentage (RP)}

Relevancy percentage was obtained by summing up the score of 'very much relevant', 'relevant' and not relevant categories, which were then converted into percentage.

\section{Relevancy Weightage (RW)}

Relevancy Weightage was obtained by the formula.

$\mathrm{RW}=\mathrm{VMR}+\mathrm{R}+\mathrm{NR} / \mathrm{MPS}$

Where,

$\mathrm{RW}=$ Relevancy Weightage

$\mathrm{VMR}=$ Very Much Relevant

$\mathrm{R}=$ Relevant

$\mathrm{NR}=$ Not Relevant

MPS= Maximum Possible Score

\section{Mean Relevancy Score (MRS)}

Mean Relevancy Score was obtained by the formula.

$\mathrm{MRS}=\mathrm{VMR}+\mathrm{R}+\mathrm{NR} / \mathrm{N}$

Where,

MRS $=$ Mean Relevancy Score

VMR=Very Much Relevant

$\mathrm{R}=$ Relevant

$\mathrm{NR}=$ Not Relevant

$\mathrm{N}=$ Number of judges

Using these above three criteria the statement were screened for their final relevancy rating. Statements having relevancy percentage above 75 , relevancy weightage above 0.75 and mean relevancy score above 2.2 were included in the scale. The final index consisted of 30 statements.

\section{Standardization of index}

In the next stage, reliability and validity of index was ascertained for standardization of the index. 
Table.1 The final employment vulnerability index comprising of 46 indicators

\begin{tabular}{|c|c|c|c|c|}
\hline SI. No. & Dimensions & $\begin{array}{l}\text { Relevancy } \\
\text { percentage }\end{array}$ & $\begin{array}{l}\text { Relevancy } \\
\text { weightage }\end{array}$ & $\begin{array}{c}\text { Relevancy mean } \\
\text { score }\end{array}$ \\
\hline 1. & Physical and mental health & 95.82 & 0.95 & 2.8 \\
\hline 2. & Education level & 100 & 1 & 3 \\
\hline 3. & Parent's education & 82.23 & 0.82 & 2.4 \\
\hline 4. & Skill oriented courses & 86.67 & 0.86 & 2.6 \\
\hline 5. & Availability of vocational training & 83.23 & 0.83 & 2.5 \\
\hline$\overline{6 .}$ & Knowledge about employment opportunities & 76.67 & 0.76 & 2.3 \\
\hline 7. & Awareness about programmes and policies & 96.67 & 0.96 & 2.9 \\
\hline 8. & Decision making ability & 83.23 & 0.83 & 2.5 \\
\hline 9. & Level for self confidence & 83.23 & 0.83 & 2.5 \\
\hline 10. & Risk taking capacity & 92.23 & 0.92 & 2.7 \\
\hline 11. & Access to credit facilities & 90 & 0.9 & 2.7 \\
\hline 12. & Financial support from self help group & 86.67 & 0.86 & 2.6 \\
\hline 13. & Incentives provided by government & 97.78 & 0.97 & 2.9 \\
\hline 14. & Availability of small scale enterprise & 90 & 0.9 & 2.7 \\
\hline 15. & Policy-relevant information about employment & 76.67 & 0.76 & 2.3 \\
\hline 16. & Technical capacity & 97.78 & 0.97 & 2.7 \\
\hline 17. & Awareness about market formation & 82.23 & 0.82 & 2.4 \\
\hline 18. & Access to commercial bank & 76.67 & 0.76 & 2.3 \\
\hline 19. & Poverty & 75.54 & 0.75 & 2.2 \\
\hline 20. & Wage rates & 77.78 & 0.77 & 2.3 \\
\hline 21. & Linkages with village level institutions & 82.23 & 0.82 & 2.4 \\
\hline 22. & Level of social participation & 92.23 & 0.92 & 2.7 \\
\hline 23. & Linkages with non-governmental organization & 76.67 & 0.76 & 2.3 \\
\hline 24. & Peer group networks & 76.67 & 0.76 & 2.3 \\
\hline 25. & Gender disparities in education and employment & 97.78 & 0.97 & 2.9 \\
\hline 26. & Security in self employment & 82.23 & 0.82 & 2.4 \\
\hline 27. & Mass media exposure & 77.78 & 0.77 & 2.3 \\
\hline 28. & Media ownership & 76.67 & 0.76 & 2.3 \\
\hline 29. & Availability to communication facilities & 96.67 & 0.96 & 2.9 \\
\hline 30. & Access to communication facilities & 97.78 & 0.97 & 2.9 \\
\hline 31. & Connectivity of area through road & 77.78 & 0.77 & 2.3 \\
\hline 32. & Availability of agricultural inputs & 97.78 & 0.97 & 2.9 \\
\hline 33. & Availability of hospitals & 76.67 & 0.76 & 2.3 \\
\hline 34. & Access to transport facilities & 92.23 & 0.92 & 2.7 \\
\hline 35. & Availability of electricity & 76.67 & 0.76 & 2.3 \\
\hline 36. & Availability of schools & 77.78 & 0.77 & 2.3 \\
\hline 37. & Access to current employment services & 83.34 & 0.83 & 2.5 \\
\hline 38. & Access to natural resources & 90 & 0.9 & 2.7 \\
\hline 39. & Availability of natural resources & 82.23 & 0.82 & 2.4 \\
\hline 40. & Drinking water facility & 92.23 & 0.92 & 2.7 \\
\hline 41. & Availability of irrigation facility & 83.34 & 0.83 & 2.5 \\
\hline 42. & Ownership of agricultural land & 97.78 & 0.97 & 2.9 \\
\hline 43. & Adopted farming practices & 92.23 & 0.92 & 2.7 \\
\hline 44. & Prevalent adaptation strategies of climate change & 90 & 0.9 & 2.7 \\
\hline 45. & Availability of biodiversity in the locale & 77.78 & 0.77 & 2.3 \\
\hline 46. & Status of environmental degradation & 82.23 & 0.82 & 2.4 \\
\hline
\end{tabular}


Table.2 Classification of employment vulnerability based on the scores
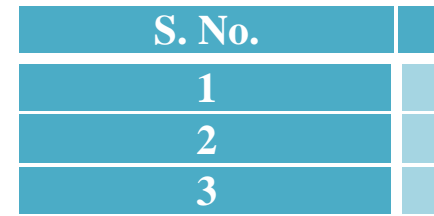

$\sqrt{2}$

Category

Highly vulnerable

Moderately vulnerable

Less vulnerable
Range

Up to 0.336

0.337 to 0.578

Above 0.578

\section{Reliability}

Reliability is the consistency or precision of measuring instrument. The index is said to be reliable when it produces results with high degree of consistency when administered to the same respondents at different items. In this study, reliability of index was determined by spilt-half method. They were divided into two halves based on odd-even numbers of statement. The scores on the odd numbered items as well as scores of the even numbered items of same respondents were correlated using the Pearson's correlation coefficient. The coefficient of internal consistency was worked out using the following formula:

$$
\begin{aligned}
& \mathrm{r}_{\mathrm{oe}}=\mathrm{N}^{\sum X Y-\left(\sum X\right)\left(\sum Y\right)} \\
& \left.\left.V_{N} \sum X^{2}\right)\left(\sum X^{2}\right)\right]\left[N \sum Y^{2}\right)\left(\sum Y^{2}\right)
\end{aligned}
$$

Where,

$\mathrm{N}=$ Number of respondents

$\mathrm{X}=$ Value of odd numbered items score

$\mathrm{Y}=$ Value of even numbered items score

The $r_{o e}$ value obtained was again correlated by using Spearman Brown formula and thus obtained the reliability. The formula used was

$\mathrm{r}_{\mathrm{tt}=} 2 \mathrm{r}_{\mathrm{oe}} / 1+\mathrm{r}_{\mathrm{oe}}$

The obtained $r_{t t}$ value was 0.79 which indicates a high reliability of the index.

\section{Content validity}

It is the property that ensures the obtained test scores as valid, if and only if it measures what it is supposed to measure. The content validity is the representativeness or sampling adequacy of the content, the substance, the matter and the topics of a measuring instrument. Content validity was used to determine the validity of the index. The opinion of the 30 judges were obtained to find out the whether the items suggested were suitable for inclusion in the index or not.

\section{Results and Discussion}

The index included 46 items. Response to each item was recorded three point continuum as scores were assigned as 3, 2 and 1 respectively. Employment vulnerability was worked out by using the following formula:

(Actual value - Minimum value) Vulnerability Index =

(Maximum value - Minimum value)

The high index value means high vulnerability but some indicators hypothesized to decrease the vulnerability with increasing value. So, index values were reversed for such indicators by subtracting them from 1 (1-index value).

On the basis of mean + standard deviation and mean -standard deviation respondents were categorized as follows (Table 1 and 2)

In the developing nation like India unemployment is the matter of concern. Unemployment among rural youth is very high, forty per cent of youth population is vulnerable regarding employment. Despite growing attention to rural employment in 
national and global policies, the needs of youth have often been neglected. The realistic causes of employment vulnerability may be social, economic, psychological, administrative, etc. Hence, it is very important to understand the employment vulnerability of rural youth so that it will help government or policy makers to make suitable policies for rural youth to get employment. The index developed to measure the employment vulnerability of rural youth in the present study is highly reliable and hence can be used in another hilly region of India.

\section{References}

CARE. 2004. Measuring livelihood impacts: A review of livelihood indicators. Livelihood monitoring unit rural livelihood program. Bangladesh. 17-22.

IFAD. 2014. Improving young rural women's and men's livelihoods - The most sustainable means of moving to a brighter future. A policy briefs.
Kanjinga, B. 2013. Youth employment and unemployment in developing countries: Macro challenges with micro perspectives. Unpublished thesis, Ph.D. University of Massachusetts Boston.

Kothari, R. 2008. Research methodology: Methods and techniques. New Delhi: New age international limited, Publishers (ISBN 10:81-224-1522-9).

Pedhazur, E.J. and Schmelkin, L.P. 1991. Measurement, design and analysis: An integrated approach. Hillsdale, NJ: Lawrence Erlbaum Associates.

Prause, J. 1991. Underemployment: A social ecological perspective. Unpublished dissertation. Ph.D. University of California, Irvine.

Shekh, T. 2003. Assessing vulnerable employment: The role of status and sector indicators in Pakistan, Namibia and Brazil. Employment Sector Working Paper No.13, International Labour Organization.

\section{How to cite this article:}

Renu Gangwar and Kashyap, S.K. 2018. Design and Development of Employment Vulnerability Index for Rural Youth. Int.J.Curr.Microbiol.App.Sci. 7(10): 2670-2675. doi: https://doi.org/10.20546/ijcmas.2018.710.310 